\title{
Metal Nanoparticles/lonic Liquid/Cellulose: Polymeric Membrane for Hydrogenation Reactions
}

\author{
Marcos Alexandre Gelesky \\ Laboratory Catalysis and Inorganic Synthesis, Universidade Federal do Rio Grande - FURG \\ Carla Weber Scheeren \\ Laboratory of Physical Chemistry School of Chemistry and Food, \\ Universidade Federal do Rio Grande - FURG
}

\begin{abstract}
Rhodium and platinum nanoparticles were supported in polymeric membranes with 10, 20 and $40 \mu \mathrm{m}$ thickness. The polymeric membranes were prepared combining cellulose acetate and the ionic liquid (IL) 1- $n$-butyl3-methylimidazolium bis(trifluoromethane sulfonyl)imide (BMI.(NTf). The presence of metal nanoparticles induced an increase in the polymeric membrane surface areas. The increase of the IL content resulted in an improvement of elasticity and decrease in tenacity and toughness, whereas the stress at break was not affected. The presence of IL probably causes an increase in the separation between the cellulose molecules that result in a higher flexibility and processability of the polymeric membrane. The $\mathrm{CA} / \mathrm{IL} / \mathrm{M}(0)$ combinations exhibit an excellent synergistic effect that enhances the activity and durability of the catalyst for the hydrogenation of cyclohexene. The CA/IL/M(0) polymeric membrane displays higher catalytic activity (up to $7.353 \mathrm{~h}^{-1}$ ) for the $20 \mu \mathrm{m}$ of CA/IL/Pt(0) and stability than the nanoparticles dispersed only in the IL.
\end{abstract}

Keywords: Hydrogenation reactions, ionic liquid, nanoparticles, polymeric membrane.

\section{Introduction}

Metal nanoparticles supported in compatible polymers hold great promise for biotechnological, catalytic and medical application ${ }^{[1]}$. For these applications, cellulose acetate (CA) is a good candidate because this polymer is hydrophilic, non-toxic, biodegradable and renewable with good processability ${ }^{[2-7]}$. Polymeric membranes have been prepared using several biopolymers (cellulose, carboxymethylcellulose, chitosan, polylactic acid $)^{[1,5-10]}$ polymers (polycaprolactone, polyaniline, polysulfone, polyurethane) and copolymers (styrene, divinylbenzene) for different applications ${ }^{[11-14]}$. Conducting polymers are a new class of polymers that has received particular interest for the production of membranes and films ${ }^{[14]}$. Biocompatible polymer systems combined with metal nanoparticles are used in various forms to incapacitate microbes by interacting with their enzymes, proteins and/or DNA (e.g., catheters, dental material, medical devices implants and burn dressings) to protect against microbial contamination.

Supported Ionic Liquid Phase (SILP) is emerging as an interesting protocol for the immobilization of transition metal catalysts since it may combine the advantages of ionic liquids (IL) with those of heterogeneous support materials ${ }^{[15-17]}$. In comparison to traditional liquid-liquid biphasic systems, higher catalytic activity and lower metal leaching can be achieved by appropriately tuning the experimental conditions ${ }^{[15,18-22]}$. These materials are prepared by the covalent attachment of IL to the support surface or by simply depositing the IL phases containing catalytically active species, usually transition metal complexes ${ }^{[20]}$ or, more rarely, metal nanoparticles ${ }^{[23,24]}$ on the surface of the support, which is usually a silica or polymeric material. However, as in classical heterogeneous catalysis, the use of active polymeric membranes ${ }^{[25-30]}$ has received little attention when compared with catalytically active inorganic membranes ${ }^{[31-34]}$. This can be attributed to the need to perform reactions in multiphase conditions at elevated temperatures that undermine the stability of the organic membrane. However, inorganic membranes (albeit with high chemical and thermal stability) ${ }^{[33]}$ may be substituted by less expensive and more versatile polymeric organic membranes. The main characteristic of a membrane is its porous structure, which selectively allows components to pass from one side to the other ${ }^{[25]}$. Moreover, the unique structure of the catalytic polymeric membranes may have other additional advantages such as immobilizing more active and selective nanosized catalysts with a reduction in particles loss, prevention of nanoparticles agglomeration, and the establishment of a porous contact region between gas and liquid phases within the polymeric membrane structure ${ }^{[34]}$. Therefore, the combination of metal nanoparticles dispersed in an ionic liquid with a polymeric organic membrane such as cellulose derivatives ${ }^{[35-40]}$ may generate new and versatile catalytic materials ${ }^{[41]}$. Indeed, we report that the association of rhodium $^{[42]}$ and platinum ${ }^{[43]}$ nanoparticles with 1-n-butyl-3-methylimidazolium bis(trifluoromethane sulfonyl)imide (BMI.(NTf) and cellulose acetate generates polymeric membrane applied in hydrogenation of cyclohexene. 


\section{Experimental Section}

\section{General}

All reactions were carried out under an argon atmosphere in modified Fischer-Porter Bottles. The halidefree 1-n-butyl-3-methylimidazolium tetrafluoroborate $\left(\mathrm{BMI}_{\mathrm{B}} \mathrm{BF}_{4}\right) \quad$ and 1 - $n$-butyl-3-methylimidazolium bis(trifluoromethane sulfonyl)imide BMI.N(Tf) ${ }_{2}$ IL were prepared according to a known procedure and dried over molecular sieves $(4 \AA)^{[44]}$. Cellulose acetate (Aldrich, $39.8 \%$ wt of acetylation content) and acetone (Merck, 99.8 $\%)$ were used to prepare the polymeric membrane. All other chemicals were purchased from commercial sources and used without further purification. NMR spectra were recorded on a Varian Inova 300 spectrometer. Infrared spectra were performed on a Bomem B-102 spectrometer. Gas chromatography analysis was performed with a Hewlett-Packard-5890 gas chromatograph with an FID and a $30 \mathrm{~m}$ capillary column with a dimethylpolysiloxane stationary phase. The nanoparticle formations were carried out in a modified Fischer-Porter bottle. The temperature was maintained at $75{ }^{\circ} \mathrm{C}$ with a hot-stirring plate connected to a digital controller (ETS-D4 IKA).

\section{Synthesis of $R h(0)$ nanoparticles}

Rhodium nanoparticles were prepared by simple hydrogen reduction ( 4 atm $\mathrm{H}_{2}$, constant pressure) of $0.026 \mathrm{~g}(0,1 \mathrm{mmol})$ of $\mathrm{RhCl}_{3} \cdot \mathrm{nH}_{2} \mathrm{O}$ dissolved in 1-n-butyl-3-methylimidazolium tetrafluoroborate (BMI. $\left.\mathrm{BF}_{4}\right)$ at $75{ }^{\circ} \mathrm{C}$ for 1 hour to yield a black suspension. Acetone $(15 \mathrm{~mL})$ was then added, and centrifugation of this mixture yielded nanoparticles of $4.8 \pm 1.1 \mathrm{~nm}$.

\section{Synthesis of Pt(0) nanoparticles}

Platinum nanoparticles were prepared by simple hydrogen decomposition ( 4 atm $\mathrm{H}_{2}$, constant pressure) of $0.054 \mathrm{~g}(0.1 \mathrm{mmol})$ of $\mathrm{Pt}_{2}(\mathrm{dba})_{3}$ dissolved in $\mathrm{BMI} \mathrm{BF}_{4}$ at $75{ }^{\circ} \mathrm{C}$ for 1.5 hours to yield a black suspension. Acetone $(15 \mathrm{~mL})$ was added, and centrifugation of this mixture yielded nanoparticles of $3.0 \pm 0.4 \mathrm{~nm}$.

\section{Preparation of polymeric membrane}

Cellulose acetate (CA) (10.0 g) was added to a reaction flask containing $90 \mathrm{~mL}$ of acetone, and the mixture was allowed to sit for $24 \mathrm{~h}$ at room temperature under a dry nitrogen atmosphere. After a viscous syrup was formed, $10.0 \mathrm{mg}(0.1 \mathrm{mmol})$ of $\mathrm{Rh}(0)$ or $10.0 \mathrm{mg}(0.05 \mathrm{mmol})$ of $\mathrm{Pt}(0)$ nanoparticles dispersed in $1.0 \mathrm{~g}$ of BMI.N(Tf $)_{2}$ were added to $5.0 \mathrm{~g}$ of the syrup, respectively. The mixtures were magnetically stirred until a homogeneous phase was obtained. polymeric membranes, designated here as CA/ $\mathrm{IL} / \mathrm{Rh}(0)$ and $\mathrm{CA} / \mathrm{IL} / \mathrm{Pt}(0)$, respectively, were prepared by spreading the homogeneous phase over a glass plate. The thickness was controlled to 10,20 and $40 \mu \mathrm{m}$ by using a spacer. The solvent was evaporated in an open atmosphere for 2 min. A similar method was used to prepare blank CA polymeric membrane, except that no $\operatorname{Rh}(0)$ or $\operatorname{Pt}(0)$ nanoparticles were used ${ }^{[45-48]}$.

\section{Scanning electron microscopy (SEM) and electron dispersive spectroscopy (EDS)}

The morphology of the polymeric membranes CA/ $\mathrm{IL} / \mathrm{Pt}(0)$ or $\mathrm{CA} / \mathrm{IL} / \mathrm{Rh}(0)$ and the electron dispersive spectroscopy analysis was performed using a JEOL model JSM 5800 with 10 and $20 \mathrm{kV}$ and magnification of 3000-10000 X.

\section{Transmission electron microscopy analysis (TEM)}

TEM was obtained using a JEOL JEM 2010 microscope operating at $200 \mathrm{kV}$ equipped with an EDS system and a JEOL JEM1200EXII operating at $120 \mathrm{kV}$. A $20 \mu \mathrm{m}$ objective aperture and slightly under focused ( $\Delta f \approx-300 \mathrm{~nm}$ ) objective lens were used to obtain the bright field TEM images. The samples were prepared by deposition of the $\mathrm{Rh}(0)$ or $\operatorname{Pt}(0)$ nanoparticles in isopropanol at room temperature on a carbon-coated copper grid. The histograms of the nanoparticle size distribution were obtained from measurements of around 300 diameters. For the analyses the nanoparticles of $\mathrm{Rh}(0)$ or $\mathrm{Pt}(0)$ immobilized in the polymeric membranes, the material was immobilized in resin and sliced with the technique of ultramicrotomy and placed on a carboncoated copper grid.

\section{$N_{2}$ adsorption-desorption isotherms}

The specific surface area and pore size distribution of the $\mathrm{CA} / \mathrm{IL} / \mathrm{Rh}(0)$ and $\mathrm{CA} / \mathrm{IL} / \mathrm{Pt}(0)$ polymeric membranes were determined at nitrogen boiling point in a homemade volumetric apparatus with a vacuum line system employing a turbo molecular Edward vacuum pump, operating with temperature of $110{ }^{\circ} \mathrm{C}$ during $2 \mathrm{~h}$. The pressure measurements were made using a capillary $\mathrm{Hg}$ barometer. The specific surface areas and pore size of the $\mathrm{CA} / \mathrm{IL} / \mathrm{Rh}(0)$ and $\mathrm{CA} / \mathrm{IL} / \mathrm{Pt}(0)$ polymeric membranes were determined from the BET multipoint method ${ }^{[49,50]}$.

\section{Infrared analysis (IR)}

The infrared spectra of the polymeric membrane were obtained using a Shimadzu FTIR, model 8300. The spectra were obtained at room temperature with a resolution of $4 \mathrm{~cm}^{-1}$ and 100 cumulative scans.

\section{Mechanical properties}

The stress-strain behaviors of the polymeric membranes were analyzed by the module of a Dynamic Mechanical Analyzer (DMA Q800 V7.0), TA Instruments, using tension membrane geometry under isothermal temperature conditions $\left(35^{\circ} \mathrm{C}\right)$. The Young's modulus, tensile stress and strain to break were calculated from the stress-strain curves obtained from the measurement.

\section{Flame atomic absorption (FAAS)}

Rhodium and platinum present in polymeric membranes were measured using a Perkin-Elmer (Boston, MA, United States) flame atomic absorption spectrometer, model Analyst 200 (FAAS), using an air-acetylene (10:2.5 $\left.1 \mathrm{~min}^{-1}\right)$ flame under optimized conditions. Hollow cathode lamps of $\mathrm{Rh}(\lambda=343.5 \mathrm{~nm})$ 
and Pt $(\lambda=265.9 \mathrm{~nm})$ from the same manufacturer were used as radiation sources.

\section{Hydrogenation reactions}

The hydrogenation reactions of cyclohexene using $\mathrm{CA} / \mathrm{IL} / \mathrm{Rh}(0)$ and $\mathrm{CA} / \mathrm{IL} / \mathrm{Pt}(0)$ polymeric membranes were carried out in a modified Fischer-Porter Bottle connected to a hydrogen tank. The fall in the hydrogen pressure in the tank was monitored with a pressure transducer interfaced through a Novus converter to a PC, and the data workup was performed with Microcal Origin 5.0 software. For the hydrogenation reaction, $210 \mathrm{mg}$ of $\mathrm{CA} / \mathrm{IL} / \mathrm{Rh}(0)$ or $\mathrm{CA} / \mathrm{IL} / \mathrm{Pt}(0)$ membrane was utilized in the Fischer-Porter reactor. The organic products were removed by simple decantation and analyzed by Gas Chromatograph.

\section{Results and Discussion}

The use of the compatible biopolymers to form polymeric membrane supporting for metal nanoparticles have to be application for catalytic reactions. The immobilization of metal nanoparticles rhodium and platinum using the advantages of ionic liquids (IL) combined with polymeric materials emerges as a new method for heterogeneous support materials. In this work, polymeric membranes of cellulose acetate, containing $\operatorname{Rh}(0)$ and $\operatorname{Pt}(0)$ nanoparticles, were prepared by the reduction of $\mathrm{RhCl}_{3}$ or decomposition of $\mathrm{Pt}_{2}(\mathrm{dba})_{3}$

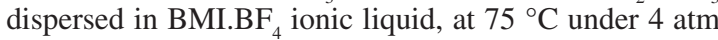
of hydrogen, as described earlier. These nanoparticles were previously characterized by XRD and TEM analysis ${ }^{[42,43]}$. The nanoparticles were irregularly shaped with a monomodal size distribution of $4.8 \pm 1.1 \mathrm{~nm}$ and $3.0 \pm 0.4 \mathrm{~nm}$ for $\operatorname{Rh}(0)^{[42]}$ and $\operatorname{Pt}(0),{ }^{[43]}$ respectively. The polymeric membranes $\mathrm{CA} / \mathrm{IL} / \mathrm{Rh}(0)$ and $\mathrm{CA} / \mathrm{IL} / \mathrm{Pt}(0)$, were characterized, and their mechanical and catalytic properties were investigated. For comparison, polymeric membranes containing the nanoparticles without the IL were also prepared. The SEM of the cross-sections of the $\mathrm{CA} / \mathrm{IL} / \mathrm{Rh}(0), \mathrm{CA} / \mathrm{Rh}(0)$ and $\mathrm{CA} / \mathrm{IL} / \mathrm{Pt}(0), \mathrm{CA} / \mathrm{Pt}(0)$ polymeric membranes are shown in Figures 1 and 2, respectively. It is clear that the morphological structure of the polymeric membranes changes with or without the presence of IL, the addition of the IL seems to cause an increase in the micro-structural order for both the CA/IL/ $\mathrm{Rh}(0)$ (Figure 1a) and $\mathrm{CA} / \mathrm{IL} / \mathrm{Pt}(0)$ (Figure 2d) polymeric membranes. In contrast, the $\mathrm{CA} / \mathrm{Rh}(0)$ polymeric membrane (Figure 1b) seems to have a scaled and porous structure. This result is in agreement with the general concept that imidazolium IL tend to act as entropic drivers for the formation nanostructure materials ${ }^{[44,45]}$.

Figures 1 and 2 shows that the $\mathrm{CA} / \mathrm{IL} / \mathrm{Rh}(0)$ and $\mathrm{CA} /$ $\mathrm{IL} / \mathrm{Pt}(0)$ films exhibit a skin that is relatively porous on the top side and a relatively porous structure over all of the polymeric membranes cross-sections.

Figure $2 \mathrm{~b}$ shows that the sample prepared in the absence of the IL also stains heterogeneously over all of the polymeric membrane cross-section, indicating the presence of $\mathrm{Pt}(0)$ nanoparticles (represented by the clear points (BSE method). In the same figure, the CA/IL/ $\operatorname{Pt}(0)$ polymeric membrane cross-section shows that the thickness of the polymeric membrane was about $21 \mu \mathrm{m}$. The BET surface areas of the polymeric membranes $(20 \mu \mathrm{m})$ obtained in CA $(5 \mathrm{~g})$ is summarized in Table 1.

The surface area of the pure cellulose acetate polymeric membrane containing $0.5 \mathrm{~g}$ of BMI.N(Tf) was $38 \mathrm{~m}^{2} / \mathrm{g}( \pm 10 \%)$, and that of the polymeric membrane with $1.0 \mathrm{~g}$ was $24 \mathrm{~m}^{2} / \mathrm{g}( \pm 10 \%)$, demonstrating a reduction in the superficial area when the amount of IL was doubled. This result suggests that an additional increment of BMI.N(Tf) ${ }_{2}$ produces an occupation of the free porous arrangement in the polymeric membrane, especially in the predominant fraction. In the case of the cellulose acetate polymeric membrane containing $\mathrm{Rh}(0)$ and $\operatorname{Pt}(0)$ nanoparticles dispersed in the IL, surface areas of $113 \mathrm{~m}^{2} / \mathrm{g}( \pm 10 \%)$ and $96 \mathrm{~m}^{2} / \mathrm{g}( \pm 10 \%)$ were obtained, respectively. This indicates that the presence of small $\mathrm{Rh}(0)$ or $\mathrm{Pt}(0)$ nanoparticles induces an augmentation in the IL/cellulose acetate polymeric membrane surface area (compare entries 1 and 2 with 3 and 4, Table 1).

TEM micrographs of the polymeric membranes $(20 \mu \mathrm{m})$ containing the metal nanoparticles in the presence of the IL (Figure 3) show that the metals are

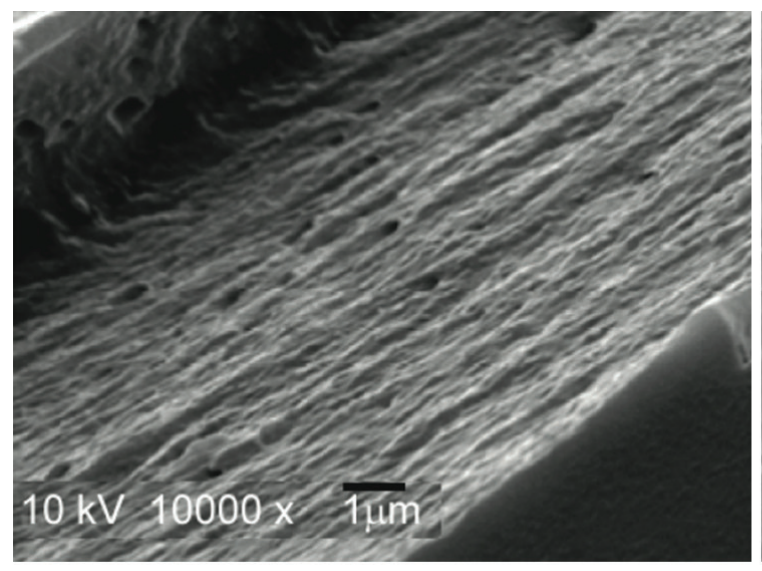

(a)

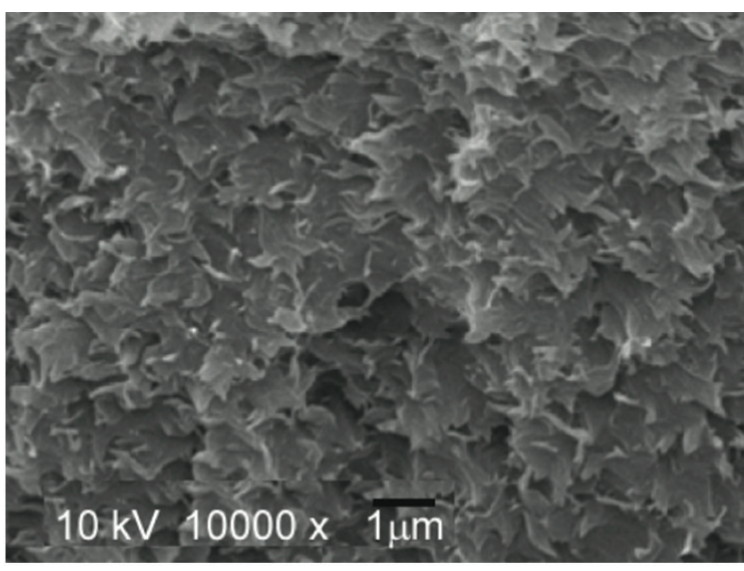

(b)

Figure 1. SEM micrographs illustrating the heterogeneous distribution on polymeric membranes of: a) $\mathrm{CA} / \mathrm{IL} / \mathrm{Rh}(0) \mathrm{and} b) \mathrm{CA} / \mathrm{Rh}(0)$. 


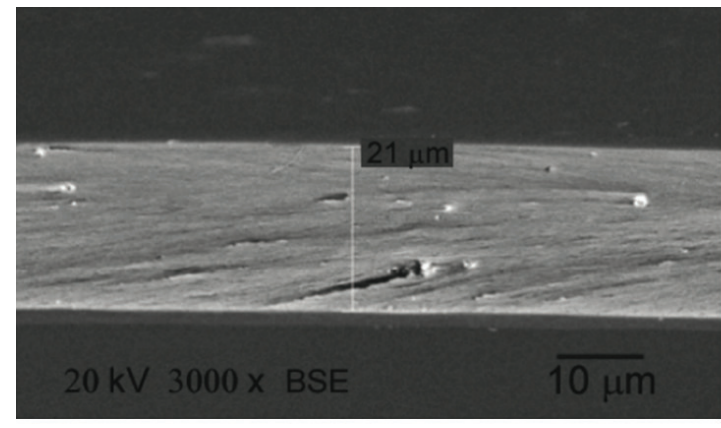

(a)

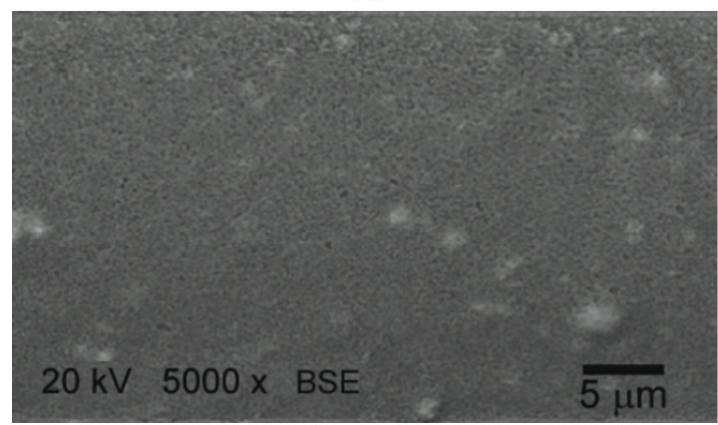

(c)

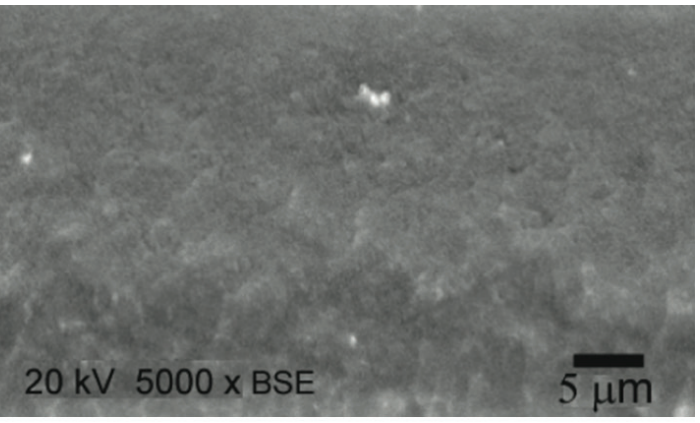

(b)

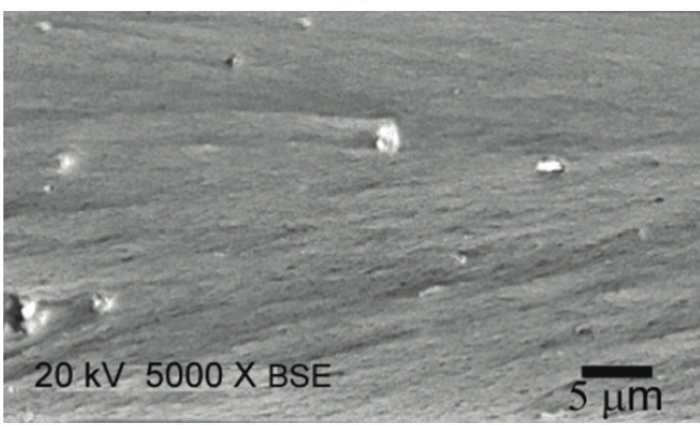

(d)

Figure 2. SEM micrographs illustrating the heterogeneous distribution on polymeric membranes of: a) thickness of $\mathrm{CA} / \mathrm{IL} / \mathrm{Pt}(0)$, b) compact polymeric membrane of $\mathrm{CA} / \mathrm{Pt}(0)$, c) $\mathrm{CA} / \mathrm{IL} / \mathrm{Pt}(0)$ showing polymeric membrane porosity and d) $\mathrm{CA} / \mathrm{IL} / \mathrm{Pt}(0)$ showing ordered in the longitudinal direction.

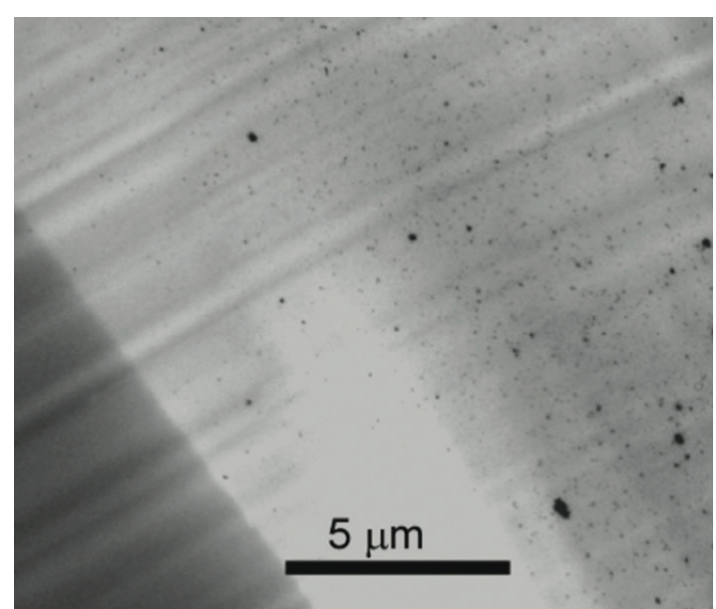

(a)

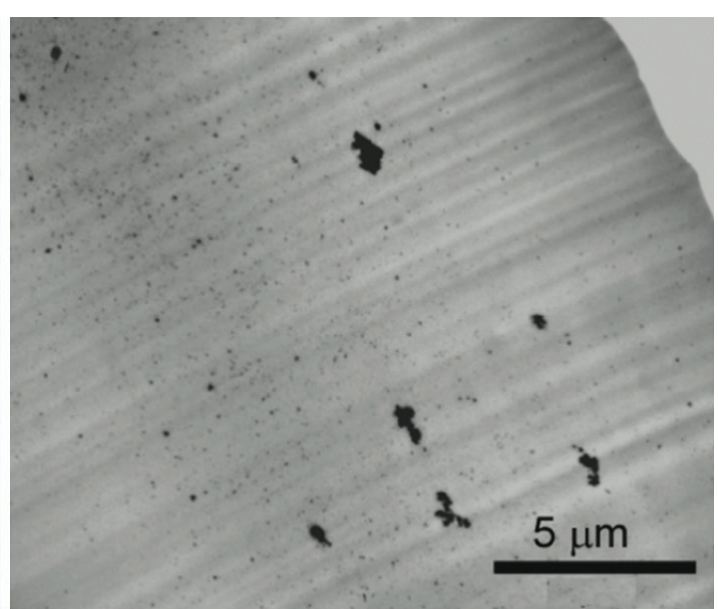

(b)

Figure 3. TEM micrographs of a) $\mathrm{CA} / \mathrm{IL} / \mathrm{Pt}(0)$ and b) $\mathrm{CA} / \mathrm{IL} / \mathrm{Rh}(0)$ polymeric membranes $(20 \mu \mathrm{m})$ prepared using $0.5 \mathrm{~g}$ of the IL.

distributed all over the polymeric membrane but are more homogeneously distributed in the case of $\operatorname{Pt}(0)$.

The concentrations of $\operatorname{Rh}(0)$ and $\operatorname{Pt}(0)$ nanoparticles incorporated in the polymeric membranes was determined using FAAS (Table 2). The concentrations are expressed as $\mu \mathrm{g} \mathrm{g}^{-1}$ and $\%(\mathrm{~m} / \mathrm{m})$ for $\mathrm{Rh}(0)$ and $\mathrm{Pt}(0)$ nanoparticles at the three thicknesses, 10, 20 and $40 \mu \mathrm{m}$. It is evident that the $\operatorname{Rh}(0)$ and $\operatorname{Pt}(0)$ metal concentration increased proportionally with increases in the polymeric membranes thickness up to $20 \mu \mathrm{m}$, after which, the material became saturated.
Table 1. Surface areas and pore volumes of the polymeric membranes $(20 \mu \mathrm{m})$ of pure cellulose acetate polymeric membranes and cellulose acetate modified polymeric membranes (with $\mathrm{M}(0)$ nanoparticles-doped BMI.N(Tf) ${ }_{2}$.

\begin{tabular}{clccc}
\hline Entry & Sample & $\mathbf{M}(\mathbf{0})(\mathbf{m g})$ & $\mathbf{I L}_{(\mathbf{g})}$ & ${ }^{\mathrm{a})} \mathbf{S}_{\mathrm{bet}}\left(\mathbf{m}^{2} / \mathbf{g}\right)$ \\
\hline 1 & $\mathrm{CA} / \mathrm{IL} / \mathrm{Rh}(0)$ & 10 & 1.0 & 113 \\
2 & $\mathrm{CA} / \mathrm{IL} / \mathrm{Pt}(0)$ & 10 & 1.0 & 96 \\
3 & $\mathrm{CA} / \mathrm{IL}$ & 0 & 0.5 & 38 \\
4 & $\mathrm{CA} / \mathrm{IL}$ & 0 & 1.0 & 24 \\
\hline
\end{tabular}

a) With metal nanoparticles with BMI-N(Tf) ${ }_{2}$. 
The IR spectra of the polymeric membranes with the same quantity of IL did not change in the presence of $\mathrm{Rh}(0)$ or $\operatorname{Pt}(0)$ (Figure 4$)$.

The presence of the IL in the support was confirmed by the stretching band at $3170 \mathrm{~cm}^{-1}$ that is due to presence of aromatic C-H groups. After impregnation of the IL in the polymeric membrane supports, a significant decrease

Table 2. $\operatorname{Rh}(0)$ and $\operatorname{Pt}(0)$ concentrations $\left(\mu \mathrm{g} . \mathrm{g}^{-1}\right)$ and values in $\%(\mathrm{~m} / \mathrm{m})$ in the polymeric membrane containing $1.0 \mathrm{~g}$ of BMI.N(Tf) (determined by FAAS ${ }^{\mathrm{a}}$ ).

\begin{tabular}{ccccc}
\hline Entry & Sample & $\begin{array}{c}\text { Thickness } \\
(\mu \mathbf{m})\end{array}$ & $\begin{array}{c}\mathbf{M}(\mathbf{0}) \\
\left(\mu \mathbf{g ~ g}^{-1}\right)\end{array}$ & $\begin{array}{c}\mathbf{M}(\mathbf{0}) \% \\
(\mathbf{m} / \mathbf{m})\end{array}$ \\
\hline 1 & $\mathrm{CA} / \mathrm{IL} / \mathrm{Rh}(0)$ & 10 & 437 & 0.04 \\
2 & $\mathrm{CA} / \mathrm{IL} / \mathrm{Rh}(0)$ & 20 & 773 & 0.08 \\
3 & $\mathrm{CA} / \mathrm{IL} / \mathrm{Rh}(0)$ & 40 & 816 & 0.08 \\
4 & $\mathrm{CA} / \mathrm{IL} / \mathrm{Pt}(0)$ & 10 & 432 & 0.04 \\
5 & $\mathrm{CA} / \mathrm{IL} / \mathrm{Pt}(0)$ & 20 & 762 & 0.08 \\
6 & $\mathrm{CA} / \mathrm{IL} / \mathrm{Pt}(0)$ & 40 & 819 & 0.07 \\
\hline
\end{tabular}

a)Analysis conditions: air-acetylene (10:2.5 $\left.1 \mathrm{~min}^{-1}\right)$; cathode lamp of $\operatorname{Rh}(\bullet=343.5 \mathrm{~nm})$ and $\operatorname{Pt}(\bullet=265.9 \mathrm{~nm})$.

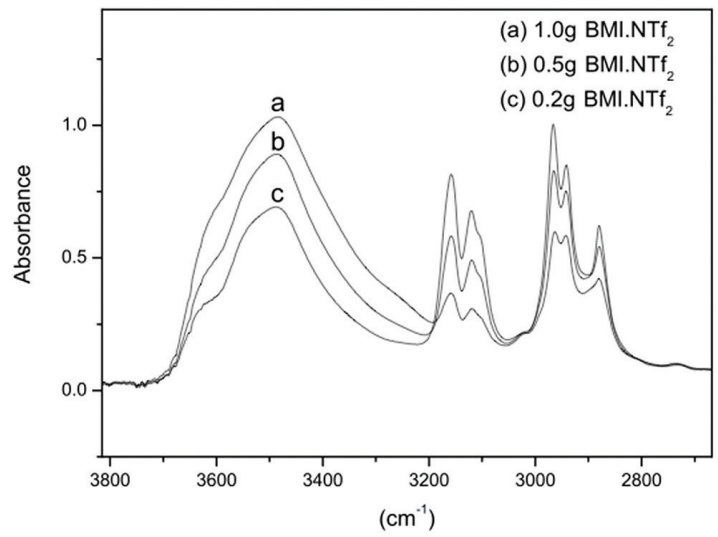

Figure 4. Infrared spectra of the cellulose acetate polymeric membranes dispersed in different amounts of BMI.N(Tf $)_{2}$.

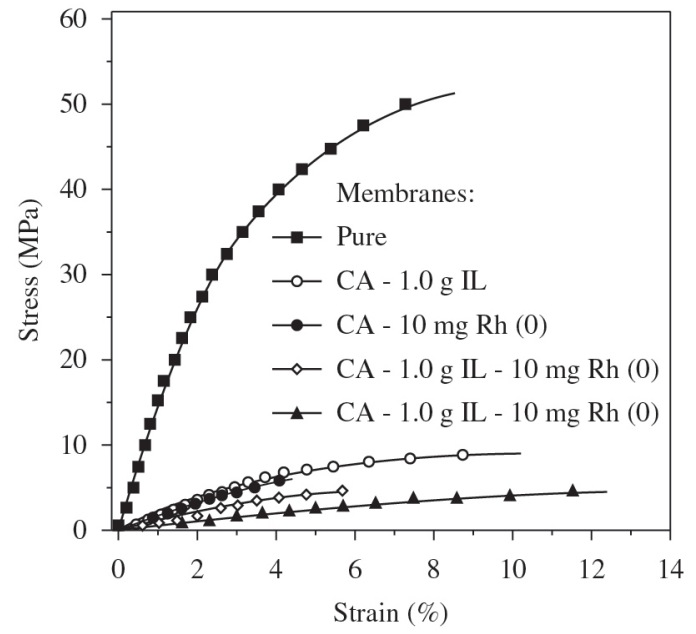

(a) is observed in the intensity of the band at $3400 \mathrm{~cm}^{-1}$, attributed to the $-\mathrm{OH}$ stretching of the pure cellulose acetate, indicating participation of the $-\mathrm{OH}$ group in the interaction with the IL. The tensile stress versus strain at break curves of the pure and modified cellulose acetate polymeric membranes are shown in Figure 5.

The stress versus strain graphic is important information about Young's modulus (slope of linear region of the plot), tenacity, and stress versus strain at the break of polymeric membrane. Figure 5 show the stress versus strain curve profiles for different compositions of polymeric membrane. In Figure 5a, the stress-strain curves are similar for the $\mathrm{CA} / \mathrm{Rh}(0), \mathrm{CA}$ $1.0 \mathrm{~g} \mathrm{IL}, \mathrm{CA}-1.0 \mathrm{~g} / 10 \mathrm{mg} \mathrm{Pt}(0)$ and CA- $1.0 \mathrm{~g} / 10 \mathrm{mg} \mathrm{Rh}(0)$ polymeric membranes when compared to the pure CA polymeric membrane. These results indicate an increase of elasticity, decreases of tenacity and toughness (area under the stress-strain curve), and reduction of Young's modulus for the CA/Rh(0), CA-1.0 g IL, CA-1.0 g/10 mg $\mathrm{Pt}(0)$ and $\mathrm{CA}-1.0 \mathrm{~g} / 10 \mathrm{mg} \mathrm{Rh}(0)$ polymeric membranes. The plasticizer effect of IL BMI.N(Tf $)_{2}$ in the CA-1.0 $\mathrm{g}$ IL polymeric membrane reduces the intermolecular forces that are usually present in the cellulose acetate. In other words, it is possible that the bis(trifluoromethane sulfonyl)imide anion of the IL strongly interacts with the hydrogen bond networks formed in the cellulose acetate polymeric membranes chains through the nitrogen atom $^{51}$. The stress-strain curve profiles of the CA-1.0 $\mathrm{g}$ $\mathrm{IL}-\mathrm{Rh}(0)$ and CA-1.0 g IL-Pt(0) polymeric membranes are shown in Figure 5a. It is observed that the initial slope (Young's modulus) decreases with a decrease of the average diameter of $4.8 \mathrm{~nm}$ and $3.0 \mathrm{~nm}$ for $\mathrm{Rh}(0)$ and $\operatorname{Pt}(0)$ nanoparticles, respectively, and consequently, the degree of elasticity of the CA-1.0 g IL-Pt(0) polymeric membrane is larger compared to the CA-1.0 $\mathrm{g} \mathrm{IL}-\mathrm{Rh}(0)$ polymeric membrane. Figure $5 \mathrm{~b}$ exhibits the range of IL quantified in the $\mathrm{CA} / \mathrm{IL} / \mathrm{Pt}(0)$ polymeric membrane composition. The catalytic properties of the $\mathrm{CA} / \mathrm{IL} / \mathrm{Rh}(0)$ and $\mathrm{CA} / \mathrm{IL} / \mathrm{Pt}(0)$ polymeric membranes were evaluated

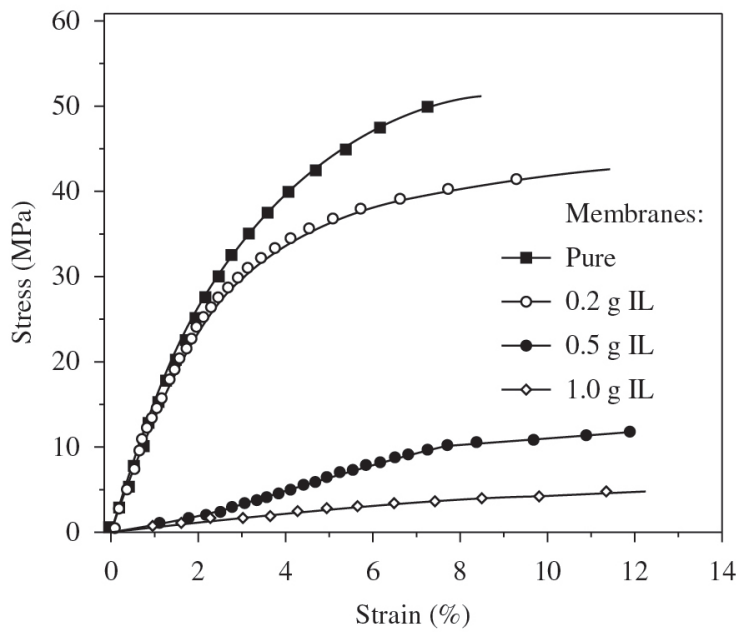

(b)

Figure 5. Stress tensile versus strain curves of the modified polymeric membranes: a) effect of different compositions on the preparation of the polymeric membranes. b) changes in the amount of IL in the composition of the polymeric membrane. 
Table 3. Hydrogenation of cyclohexene with $\mathrm{CA} / \mathrm{IL} / \mathrm{Rh}(0)$ and $\mathrm{CA} / \mathrm{IL} / \mathrm{Pt}(0)$ polymeric membranes using different concentrations of BMI.N(Tf $)_{2}^{\text {a) }}$.

\begin{tabular}{ccccccc}
\hline Entry & Sample & Thickness $(\mu \mathbf{m})$ & Time $(\mathbf{h})^{\mathbf{b})}$ & Metal $(\mathbf{m g})$ & ${\text { BMI.N }(\mathbf{T f})_{2}(\mathbf{g})}_{\text {TOF }^{\mathbf{b})}\left(\mathbf{h}^{-1}\right)}$ \\
\hline 1 & $\mathrm{CA} / \mathrm{IL} / \mathrm{Rh}(0)$ & 10 & 1.6 & 0.084 & 1.0 & 961 \\
2 & $\mathrm{CA} / \mathrm{IL} / \mathrm{Pt}(0)$ & 10 & 1.4 & 0.084 & 1.0 & 2.083 \\
3 & $\mathrm{CA} / \mathrm{IL} / \mathrm{Rh}(0)$ & 40 & 0.5 & 0.168 & 1.0 & 1.562 \\
4 & $\mathrm{CA} / \mathrm{IL} / \mathrm{Pt}(0)$ & 40 & 0.6 & 0.147 & 1.0 & 2.451 \\
5 & $\mathrm{CA} / \mathrm{IL} / \mathrm{Rh}(0)$ & 20 & 0.7 & 0.168 & 0.2 & 1.095 \\
6 & $\mathrm{CA} / \mathrm{IL} / \mathrm{Rh}(0)$ & 20 & 0.2 & 0.168 & 0.5 & 3.906 \\
7 & $\mathrm{CA} / \mathrm{IL} / \mathrm{Rh}(0)$ & 20 & 0.3 & 0.168 & 1.0 & 2.551 \\
8 & $\mathrm{CA} / \mathrm{IL} / \mathrm{Pt}(0)$ & 20 & 0.3 & 0.168 & 0.2 & 4.807 \\
9 & $\mathrm{CA} / \mathrm{IL} / \mathrm{Pt}(0)$ & 20 & 0.2 & 0.168 & 0.5 & 7.353 \\
10 & $\mathrm{CA} / \mathrm{IL} / \mathrm{Pt}(0)$ & 20 & 0.6 & 0.168 & 1.0 & 2.777 \\
11 & $\mathrm{IL} / \mathrm{Rh}(0)$ & - & 0.032 & 5.0 & 1.0 & 833 \\
12 & $\mathrm{IL} / \mathrm{Pt}(0)$ & - & 0.15 & 5.0 & 1.0 & 329 \\
13 & $\mathrm{CA} / \mathrm{IL}$ & 40 & 4.0 & 0.0 & 1.0 & 0 \\
\hline
\end{tabular}

a) Reactions conditions: membrane CA/IL/Metal(0): $210 \mathrm{mg}$; cyclohexene $12.5 \mathrm{mmol}, 4$ bar of $\mathrm{H}_{2}, 75{ }^{\circ} \mathrm{C}$; ${ }^{\text {b }}$ Time for $10 \%$ cyclohexene conversion (determined by GC).

in hydrogenation reactions of cyclohexene (Table 3). For example, higher catalytic activity (TOF) was observed with $20 \mu \mathrm{m}$ polymeric membranes employing $1.0 \mathrm{~g}$ of the IL compared to the $10 \mu \mathrm{m}$ and $40 \mu \mathrm{m}$ polymeric membranes (compare entries 1,3 and 7 for $\operatorname{Rh}(0)$ and entries and 2, 4 and 10 for $\operatorname{Pt}(0)$ in Table 3. This is probably related to the relatively low stability of the $10 \mu \mathrm{m}$ polymeric membranes, which undergo agglomeration during the hydrogenation, thus reducing the exposed area of the catalytically active species, and the membrane with $40 \mu \mathrm{m}$ shown a large thickness for effective interaction between the substrate and nanoparticles. It is clear from the TOF data that the CA/IL/Pt(0) polymeric membranes are more active than those without the cellulose (compare entries 9 and 12 of Table 3, for example). This result is in line with those results observed for other supported IL phase catalysts ${ }^{[19]}$. It is also evident that the best relation between the two materials is $0.5 \mathrm{~g}$ of the $\mathrm{IL}$ and $5.0 \mathrm{~g}$ of cellulose acetate (compare entries 5, 6 and 7 and 8, 9 and 10 of Table 3 for $\operatorname{Rh}(0)$ and $\operatorname{Pt}(0) 20 \mu \mathrm{m}$ thickness polymeric membranes, respectively).

\section{Conclusions}

The use of the biopolymer cellulose acetate (CA) support for $\mathrm{Pt}(0)$ or $\mathrm{Rh}(0)$ nanoparticles dispersed in IL generated functionalized polymeric membranes in which the mechanical, thermal and chemical stability was related to the amount of IL used. Therefore, the introduction of the IL is probably causing an increase in the distance between the cellulose molecules that result in a higher flexibility, and better formability of the polymeric membranes. The biopolymer/ionic liquid/metal nanoparticles, form the polymeric membranes, exhibits an excellent effect that enhances the activity and durability of the catalyst for the hydrogenation of cyclohexene.

\section{Acknowledgments}

Thanks are due to the following Brazilian Agencies: CNPq, CAPES and FAPERGS for fellowships and partial financial support.

\section{References}

1. Scheeren, C. W.; Hermes, V.; Bianchi, O.; Hertz, P. F.; Dias, S. L. \& Dupont, J. - J Nanosci Nanotechnol., 11, p.1 (2011).

2. Ding, B.; Kimura, E.; Sato, T.; Fujita, S. \& Shiratori, S. - Polymer., 45, p.1895 (2004). http://dx.doi.org/10.1016/j. polymer.2004.01.026

3. Nagendran, A. \& Mohan, D. R. - Polym. Adv. Technol., 19, p.24 (2008). http://dx.doi.org/10.1002/pat.965

4. Edgar, K. J.; Buchanan, E. K. C. M.; Debenham, J. S.; Rundquist, P. A.; Seiler, B. D.; Shelton, M. C. \& Tindall, D. - Prog. Polym. Sci., 26, p.1605 (2001). http://dx.doi. org/10.1016/S0079-6700(01)00027-2

5. Rezende, C. A.; Luchesi, C.; Barbo, M. L. P. \& Duek, E. A. R. - Polímeros, 15, p.232 (2005). http://dx.doi.org/10.1590/ S0104-14282005000300015

6. Maria, L. C. S.; Santos, A. L. C.; Oliveira, P. C.; Valle, S. S.; Barud, H. S.; Messaddeq, Y. \& Ribeiro, S. J. L. - Polímeros, 20, p.72 (2010). http://dx.doi.org/10.1590/ S0104-14282010005000001

7. Quadros, C. C.; Faria, V. W.; Klein, M. P.; Hertz, P. F. \& Scheeren, C. W. - J Nanotechnol., 2013, p.1 (2013). http:// dx.doi.org/10.1155/2013/140273

8. Stoimenov, P. K.; Klinger, R. L.; Marchin, G. L. \& Klabunde, K. J. - Langmuir., 18, p.6679 (2002). http:// dx.doi.org/10.1021/la0202374

9. Scheeren, C. W.; Hertz, P. F.; Hermes, V. \& Dupont, J. - Process Biochem., 22, p.1123 (2011).

10. Santa-Maria, L. C.; Oliveira, R. O.; Merçon, F.; Borges, M. E. R. S. P.; Barud, H. S.; Ribeiro, S. J. L.; Messaddeq, Y. \& Wang, S. H. - Polímeros, 20, p.227 (2010).

11. Müller, F.; Ferreira, C. A.; Amado, F. D. R. \& Rodrigues, M. A. S. - Polímeros, 21, p.259 (2011). http://dx.doi. org/10.1590/S0104-14282011005000053

12. Bellincanta, T.; Poletto, P.; Thürmer, M. B.; Duarte, J.; Toscan, A. \& Zeni, M. - Polímeros, 21, p.229 (2011). http:// dx.doi.org/10.1590/S0104-14282011005000045

13. Thürmer, M. B.; Poletto, P.; Marcolin, M.; Ferreira, D. G. \& Zeni, M. - Polímeros, 20, p.170 (2010). http://dx.doi. org/10.1590/S0104-14282010005000037 
14. Barud, H. S.; Ribeiro, S. J. L.; Carone, C. L. P.; Ligabue, R.; Einloft, S. \& Jahno V. D. - Polímeros, 23, p.135 (2013).

15. Steinrück, H. P.; Libuda, J.; Wasserscheid, P.; Cremer, T.; Kolbeck, C.; Laurin, M.; Maier, F.; Sobota, M.; Schulz, P. S. \& Stark, M. - Adv. Mater., 23, p.2571 (2011). PMid:21520462. http://dx.doi.org/10.1002/ adma.201100211

16. Werner, S.; Haumann, M. \& Wasserscheid, P. - Annual Rev. Chem. Biomolecular Eng., 1, p.203 (2010). PMid:22432579. http://dx.doi.org/10.1146/annurevchembioeng-073009-100915

17. Donato, R. K.; Migliorini, M. V.; Benvegnú, M. A.; Stracke, M. P.; Gelesky, M. A.; Pavan, F. A.; Schrekker, C. M. L.; Benvenutti, E. V.; Dupont, J. \& Schrekker, H. S. - J Solgel Sci Technol., 49, p.71 (2009). http://dx.doi.org/10.1007/ s10971-008-1829-6

18. Bianchini, C. \& Giambastiani, G. - Chemtracts, 16, p.301 (2003).

19. Kohler, F.; Roth, D.; Kuhlmann, E.; Wasserscheid, P. \& Haumann, M. - Green Chem., 12, p.979 (2010). http:// dx.doi.org/10.1039/c004883f

20. Feng, C. L.; Wang, Y. H. \& Jin, Z. L. - Prog. Chem., 17, p.209 (2005).

21. Haumann, M.; Dentler, K.; Joni, J.; Riisager, A. \& Wasserscheid, P. - Adv. Synth. Catal., 349, p.425 (2007). http://dx.doi.org/10.1002/adsc.200600413

22. Webb, P. B.; Kunene, T. E. \& Cole-Hamilton, D. J. - Green Chem., 7, p.373 (2005). http://dx.doi.org/10.1039/ b416713a

23. Gelesky, M. A.; Chiaro, S. S. X.; Pavan, F. A.; dos Santos, J. H. Z. \& Dupont, J. - Dalton Trans., 47, p.5549 (2007). PMid:18043816. http://dx.doi.org/10.1039/b708111a

24. Zornoza, B.; Irusta, S.; Tellez, C. \& Coronas, J. - Langmuir., 25, p.5903 (2009). PMid:19391574. http:// dx.doi.org/10.1021/la900656z

25. Bottino, A.; Capannelli, G.; Comite, A.; Del Borghi, A. \& Di Felice, R. - Sep. Purif. Technol., 34, p.239 (2004). http:// dx.doi.org/10.1016/S1383-5866(03)00196-5

26. Centi, G. \& Perathoner, S. - Catal. Today., 79, p.3 (2003). http://dx.doi.org/10.1016/S0920-5861(03)00036-1

27. Khatib, S. J. \& Oyama, S. T. - Sep. Purif. Technol., 11, p.20 (2013). http://dx.doi.org/10.1016/j.seppur.2013.03.032

28. Fritsch, D. \& Bengtson, G. - Catal. Today., 118, p.121 (2006). http://dx.doi.org/10.1016/j.cattod.2006.01.039

29. Ozdemir, S. S.; Buonomenna, M. G. \& Drioli, E. - Appl Catal A Gen., 307, p.167 (2006). http://dx.doi.org/10.1016/j. apcata.2006.03.058

30. Kragl, U. \& Dwars, T. - Trends Biotechnol., 19, p. 442 (2001). http://dx.doi.org/10.1016/S0167-7799(01)01766-8

31. Belyakova, L. A.; Linkov, V. M.; Belyakov, V. N. \& Bulavina, T. V. - Sep. Purif. Technol., 14, p.117 (1998). http://dx.doi.org/10.1016/S1383-5866(98)00066-5

32. Tonkovich, A. L. Y.; Zilka, J. L.; Jimenez, D. M.; Roberts, G. L. \& Cox, J. L. - Chem. Eng. Sci., 51, p.789 (1996). http://dx.doi.org/10.1016/0009-2509(95)00325-8

33. Cuffe, L.; MacElroy, J. M. D.; Tacke, M.; Kozachok, M. \& Mooney, D. A. J. - Membr. Sci., 272, p.6 (2006). http:// dx.doi.org/10.1016/j.memsci.2005.12.021
34. Xu, J.; Dozier, A. \& Bhattacharyya, D. J. - Nanop. Res., 7, p.449 (2005). http://dx.doi.org/10.1007/s11051005-4273-3

35. Cai, J.; Kimura, S.; Wada, M. \& Kuga, S. - Biomacromolecules, 10, p.87 (2009). PMid:19053296. http://dx.doi.org/10.1021/bm800919e

36. Bagheri, M.; Rodriguez, H.; Swatloski, R. P.; Spear, S. K.; Daly, D. T. \& Rogers, R. D. - Biomacromolecules, 9 , p.381 (2008). PMid:18163541. http://dx.doi.org/10.1021/ bm701023w

37. El Seoud, O. A.; Koschella, A.; Fidale, L. C.; Dorn, S. \& Heinze, T. Biomacromolecules, 8, p.2629 (2007). PMid:17691840. http://dx.doi.org/10.1021/bm070062i

38. Viswanathan, G.; Murugesan, S.; Pushparaj, V.; Nalamasu, O.; Ajayan, P. M. \& Linhardt, R. J. - Biomacromolecules, 7, p.415 (2006). PMid:16471910. http://dx.doi.org/10.1021/ bm050837s

39. Chiba, R.; Nishio, Y.; Sato, Y.; Ohtaki, M. \& Miyashita, Y. - Biomacromolecules, 7, p.3076 (2006). PMid:17096534. http://dx.doi.org/10.1021/bm060567t

40. Turner, M. B.; Spear, S. K.; Holbrey, J. D.; Daly D. T. \& Rogers, R. D. Biomacromolecules, 6, p.2497 (2005). PMid:16153085. http://dx.doi.org/10.1021/bm050199d

41. Migowski, P. \& Dupont, J. - Chem. Eur. J., 13, p.32 (2007). PMid:17115465. http://dx.doi.org/10.1002/chem.200601438

42. Gelesky, M. A.; Umpierre, A. P.; Machado, G.; Correia, R. R. B.; Magno, W. C.; Morais, J.; Ebeling, G. \& Dupont, J. J. - Am. Chem. Soc., 127, p.4588 (2005). PMid:15796520. http://dx.doi.org/10.1021/ja042711t

43. Scheeren, C. W.; Machado, G.; Teixeira, S. R.; Morais, J.; Domingos, J. B. \& Dupont, J. J. - Phys. Chem. B, 110, p.13011 (2006). PMid:16805608. http://dx.doi. org/10.1021/jp0623037

44. Cassol, C. C.; Ebeling, G.; Ferrera, B. \& Dupont, J. - Adv. Synth. Catal., 348, p.243 (2006). http://dx.doi.org/10.1002/ adsc. 200505295

45. Campos, E. A. \& Gushikem, Y. J. - J Colloid Sci., 193, p.121 (1997). http://dx.doi.org/10.1006/jcis.1997.5051

46. Kwon, J. W.; Yoon, S. H.; Lee, S. S.; Seo, K. W. \& Shim, I. W. - Bull. Korean Chem. Soc., 26, p.837 (2005).

47. Rodrigues, U. P.; Gushikem, Y.; Gonçalves, M. D.; Cachichi, R. C. \& de Castro, S. C. - Chem. Mater., 8, p.1375 (1996).

48. Feldman, J. \& Orchin, M. J. - Mol. Catal., 63, p.213 (1990). http://dx.doi.org/10.1016/0304-5102(90)85145-8

49. Barrett, E. P.; Joyner, L. G. \& Halenda, P. P. - J. Am. Chem. Soc., 73, p.373 (1951). http://dx.doi.org/10.1021/ ja01145a126

50. Brunauer, S. - Langmuir, 3, p.3 (1987).

51. Zhu, S. D.; Wu, Y. X.; Chen, Q. M.; Yu, Z. N.; Wang, C. W.; Jin, S. W.; Ding, Y. G. \& Wu, G. - Green Chem., 8, p.325 (2006). http://dx.doi.org/10.1039/b601395c

Received: $12 / 13 / 12$

Revised: 04/15/13

Accepted: 04/25/13 